\title{
SOLAR ENERGY POTENTIAL AND ASSESSMENT OF CSP PLANT ACCOUNTING FOR SUSTAINABILITY IN SUDAN
}

\author{
Dr. Salaheldin Hassabelgabo Abdelrazig Ibrahim, Dr. Osama Mohammed Elmardi Suleiman Khayal \\ Department of Mechanical Engineering, Faculty of Engineering and Technology, \\ Nile Valley University, Atbara - Sudan
}

\begin{abstract}
Sudan is one of the East Africa countries that have endured considerable economic strain with the loss of substantial oil following the separation of South Sudan in July 2011, but it is lucky enough to have an abundant solar energy potential resources with plenty of water resources and a large area of lands. River Nile State (RNS) one of Sudan states characterized by a huge potential of national resources. The location of RNS is covered by a Direct Normal Radiation above $1800 \mathrm{kWh} / \mathrm{m}^{2} /$ year, the resources available in the State is quite sufficient to support nexus between energy, food, water, and land use to offers an approach for multi-scale, integrated assessment of this nexus. The analysis and performance of the proposed parabolic trough power plant are done by using SAM software created by National Renewable Energy Laboratory's (NREL) SAM software. The selected parabolic trough concentrated power plant system has a capacity of 100 MW nameplate capacity and 6 hours thermal Energy storage (TES). The simulation of solar energy potential contribution (quantity) and convenience (quality) of concentrated solar power (CSP) as alternative sources for the production of electricity in River Nile State. The annual electricity power generated for the 6 localities of River Nile State is calculated to be 389 GWh Abu Hamad, 381 GWh Atbra, 385 GWh Barbar, 383 GWh El Damer, El Matammah 364 GWh and 382 GWh Shendi respectively. For sustainability, the results show that fossil fuel can be the preserve considerably in this state and can achieve about 76 Million Cubic Meters of $\mathrm{CO} 2$ emissionreducing and 31 Million Cubic Meters Natural gas-saving with the line of the sustainable development program. For nexus issues, solar field area (land) is $\mathbf{5 8 7}$ acres with nonsolar field land area with a multiplier of 1.4 which gives a total plant area of 822 acres $(8.22$ acres per MW of power capacity) with Average solar radiation 2,587 Wh/m2/year. The energy outputs are: 562 GWh thermal annually (provided by solar radiation); and 389 electricity annually (produced by the plant) for Abu Hamad locality the higher solar potential resources, Besides a Total Annual Water usage is $84,238 \mathrm{~m}^{3}$.
\end{abstract}

Keywords- River Nile State, CSP, Abu Hamad, Parabolic trough, Sudan

\section{INTRODUCTION}

In the recent century, the international and national concerns is over food, water, and energy security due to the growing demands placed on land and other natural resources by global population increase and climate and other environmental changes present the need of resources accounting for sustainability by the nexus between Energy, Food, Water and Land use [1]. For energy demand fossil fuels (non-renewable) have the main role to supply this energy requirement among different types of energy sources [2]. The global increase in the number of population and the scope of wealth leads to greater energy consumption. As result there is a lack of resources especially energy and drinking water [3], it is estimated that the consumption of electrical energy will double in the next $15-20$ years [4], while the estimates of the world primary energy consumption is $80 \%$ of the supply provided by fossil fuel [5]. Renewable energy sources are considered a valuable alternative source of energy since they are sustainable, cheap, and environmentally friendly [6]. Solar energy is rightly seen as a huge opportunity for Africa, both at utility-scale and off-grid. Deployment is low today, but it is expanding fast. Recent new utility-scale capacity additions include the first phases of the 1.6 gigawatts $(\mathrm{GW})$ solar photovoltaics (PV) park at Benban in Egypt and the $510 \mathrm{MW}$ Noor solar concentrating solar power development in Morocco, both of which are among the world largest of their kind. In East Africa, Kenya commissioned the 310 MW Lake Turkana Wind Power plant and the 185 MW Olkaria Geothermal Power Plant, both among Africa's largest in their respective technologies. Large-scale projects have successfully been confirmed in other countries and many more are underway in Angola, Ethiopia, South Africa, Senegal, Uganda, and Zambia, among others. A study undertaken by the International Renewable Energy Agency (IRENA, 2014) assessed the theoretical potential of a range of renewable energy technologies in Africa (Figure 1). It estimated that Africa's solar PV theoretical potential could provide the continent with more than $660000 \mathrm{TWh}$ of electricity a year, far above its projected needs. East Africa was identified as 


\section{International Journal of Engineering Applied Sciences and Technology, 2020 \\ Vol. 5, Issue 7, ISSN No. 2455-2143, Pages 13-19 \\ Published Online November 2020 in IJEAST (http://www.ijeast.com)}

having the highest theoretical potential (more than 200000 TWh/year), followed by Southern Africa (more than 160000 TWh/year) [7]. Sudan is one of the East Africa countries that has endured considerable economic strain with the loss of substantial oil following the separation of South Sudan in July 2011, but it lucky enough to have abundant solar energy potential resources with plenty of water resources and a large area of lands.

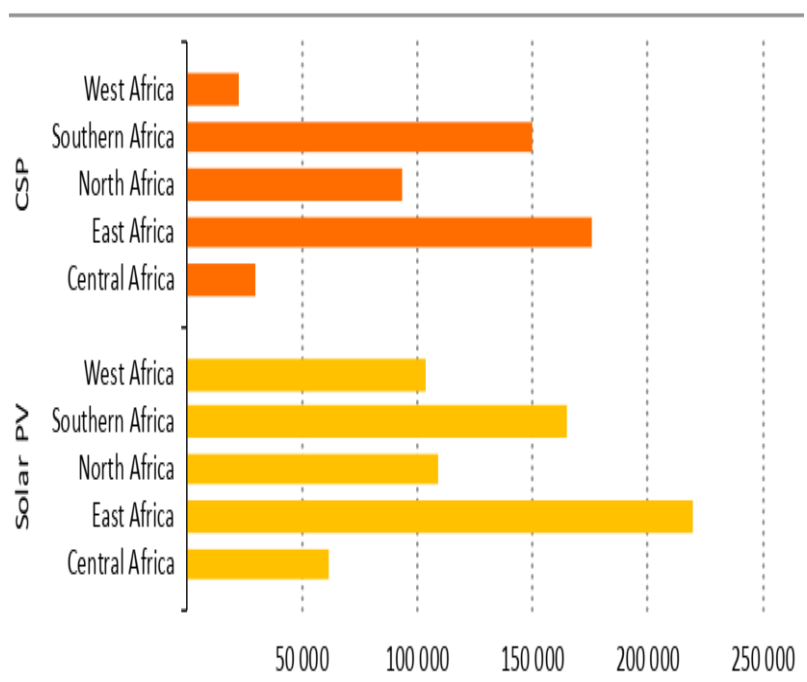

TWh

\section{East Africa and Southern Africa contain the highest solar resource potential}

Note: CSP = concentrating solar power.

Source: IRENA (2014).

Fig.1. East and Southern Africa solar resources potential

The objective of this study was to generate an integrated assessment of the solar energy potential contribution (quantity) and convenience (quality) of concentrated solar power (CSP) as alternative sources for the production of electricity in the River Nile State of Sudan, where the state is characterized by its water and land resources for agriculture and food production. The simulation tool that used to simulate the proposed CSP system, is the System Advisor Model (SAM), a free techno-economic software model that facilitates decision-making for people in the renewable energy industry [8].

\section{A. Electrical Energy Situation in Sudan}

In Sudan 2019, the total generated and imported energy from Ethiopia to the national grid is recorded to be $17,052.996$ gigawatt-hours with an increase of $7.2 \%$ from the previous year. The National grid divided into four main network regions, the consumption of energy in the greater Khartoum network region is 10,865.7 gigawatt-hours, Al Jazeera network region consumed 3,711.8 gigawatt-hours, the eastern network region consumed 1,548.98 gigawatt-hours, and the northern network grid (Nile +Northern state) consumed $2,559.42$ gigawatt-hours. The percentage of load sharing is shown in figure 2 below [9]

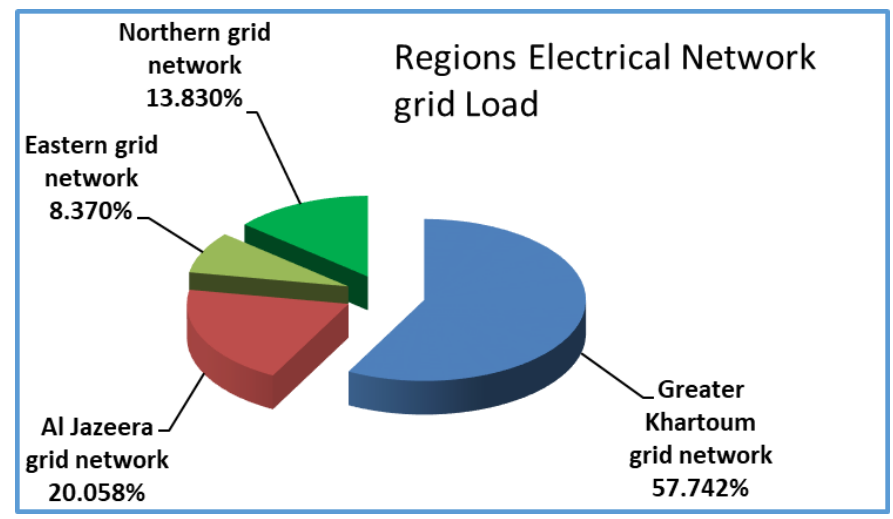

Fig.2. Sudan regions grid load

The percentage of thermal generation in 2019 was $38.12 \%$, from the total energy generated of 16,714.75 gigawatt hours. The types of fuel used to produce this amount of energy is as shown in table 1 and Figure 3, below [9].

Table -1 Quantities of Different types of Fuel consumed

\begin{tabular}{|c|c|}
\hline Type of Fuel & Quantity (Ton) \\
\hline Gas Oil & $\mathbf{3 4 , 0 0 3 . 0}$ \\
\hline Heavy Fuel oil (HFO) & $\mathbf{3 4 , 0 0 4 . 3}$ \\
\hline Heavy Coke (HC) & $\mathbf{3 8 , 7 8 5 . 0 6}$ \\
\hline Light Fuel Oil (LFO) & $\mathbf{0}$ \\
\hline Petroleum Coke & $\mathbf{7 5 , 5 7 0 . 2 5}$ \\
\hline Crude Oil & $\mathbf{7 3 7 , 6 5 7 . 2 5}$ \\
\hline
\end{tabular}

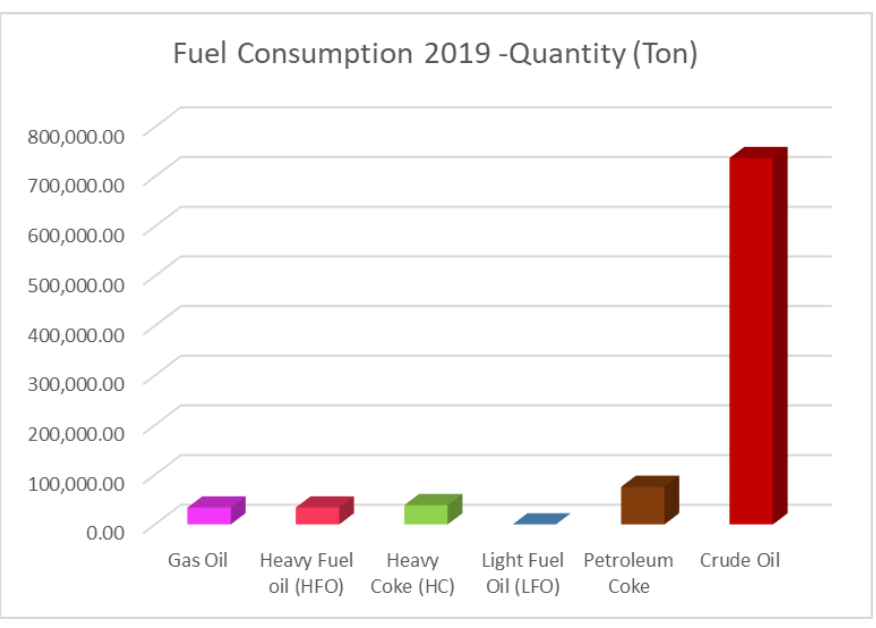

Fig.3. Sudan fuel consumption electric generation

Recently in Sudan 2020 there are shortage and limited supply of fossil hydrocarbon resources. Due to the shortage of fossil 


\section{International Journal of Engineering Applied Sciences and Technology, 2020 \\ Vol. 5, Issue 7, ISSN No. 2455-2143, Pages 13-19 \\ Published Online November 2020 in IJEAST (http://www.ijeast.com)}

fuels supply, Sudan faced with a situation of a week energy security, this including shortage of electric power supply. With a considerations to the negative impact of $\mathrm{CO} 2$ emissions on the global environment, all these facts encouraging the tendency and dictating the increasing usage of renewable energy resources.

\section{CONCENTRATING SOLAR POWER PLANTS TECHNOLOGY}

Concentrated solar power (CSP) is that the presumable candidate for providing the bulk of this renewable energy because it's amongst the foremost cost-effective renewable electricity technologies and since its supply is not restricted if the energy generated is transported from the world's solar belt to the population centres Three main technologies as shown in Figure 4 are identified during the past decades for generating electricity within the ten $\mathrm{kW}$ to several thousand MW ranges [10].

dish/engine technology, which can directly generate electricity in isolated locations

Parabolic and Fresnel trough technology, which produces high-pressure superheated steam

$\square \quad$ solar tower technology, which produces air above $1000^{\circ} \mathrm{C}$ or synthesis gas for gas turbine

The NREL's SAM software (System Advisor Model) usually familiar with evaluate the plants energetic and economic performances and presents desirable outputs like as annual energy output, capacity factor and efficiency. Several types of research have studied CSP plants for various consideration in some countries. Abbas et al. [11] had an assessment of a 100 MW plant for electricity generation based on parabolic trough technology in four typical sites of Algerian climate conditions by using SAM software. Donaji et al. [12] used SAM to assess an annual production between the parabolic trough systems and power tower in Mexico and Spain. Malagueta et al. [13], simulated four sorts of $100 \mathrm{MW}$ CSP plants with parabolic troughs (simple plants, plants with hybridization and plants with thermal energy storage) supported the SAM at two sites: Bom Jesus da Lapa and Campo Grande. Purohit [14] had a Techno-commercial feasibility of 4 sorts of CSP plants for 23 locations in India.

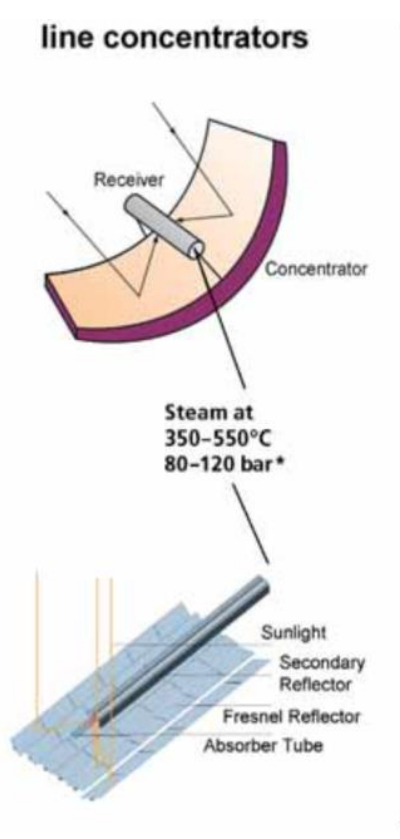

point concentrators

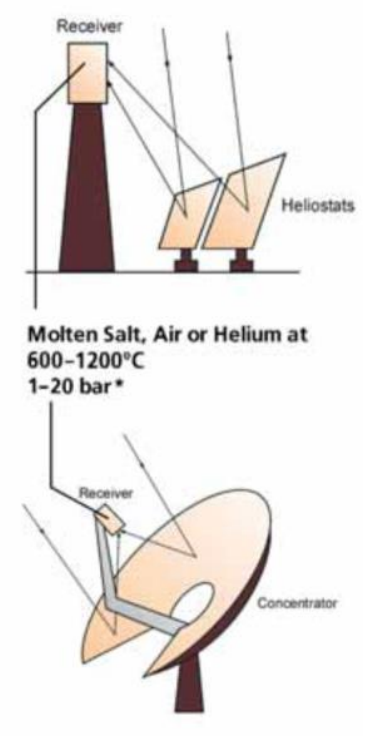

Fig.4. Technologies for concentrating solar radiation: left side parabolic and linear Fresnel troughs, right side central solar tower receiver and parabolic dish

\section{RIVER NILE STATE (SUDAN) TOPOGRAPHY AND ITS SOLAR POTENTIAL}

River Nile State is located between Latitudes 16-22 north and Longitudes 32-35 south. From the North, it's bordered by the Arab Republic of Egypt from the East Kassala and the Red Sea States and on the South Khartoum State and from West the Northern State as shown in Figure 6. The River Nile traverses the lands of the State on its way Northwards towards its Mouth, where it joined by Atbara River. The State's area is 122.1 thousand square Kilometers and estimated population of 1,027,534 [15]. The River Nile State depends on its economy on traditional and modern agriculture. The most important agricultural products include Egyptian beans, which are grown in Berber, the third city in the state after Atbara and Damer. Its agricultural products also include vegetables and fruits, and it is considered the first state in Sudan in the production of horticultural crops and fodder. There are more than 30 agricultural projects in it, including food security projects (Atbara, Al Damer, Berber) Al-Zaidab Al-Zaid project. 


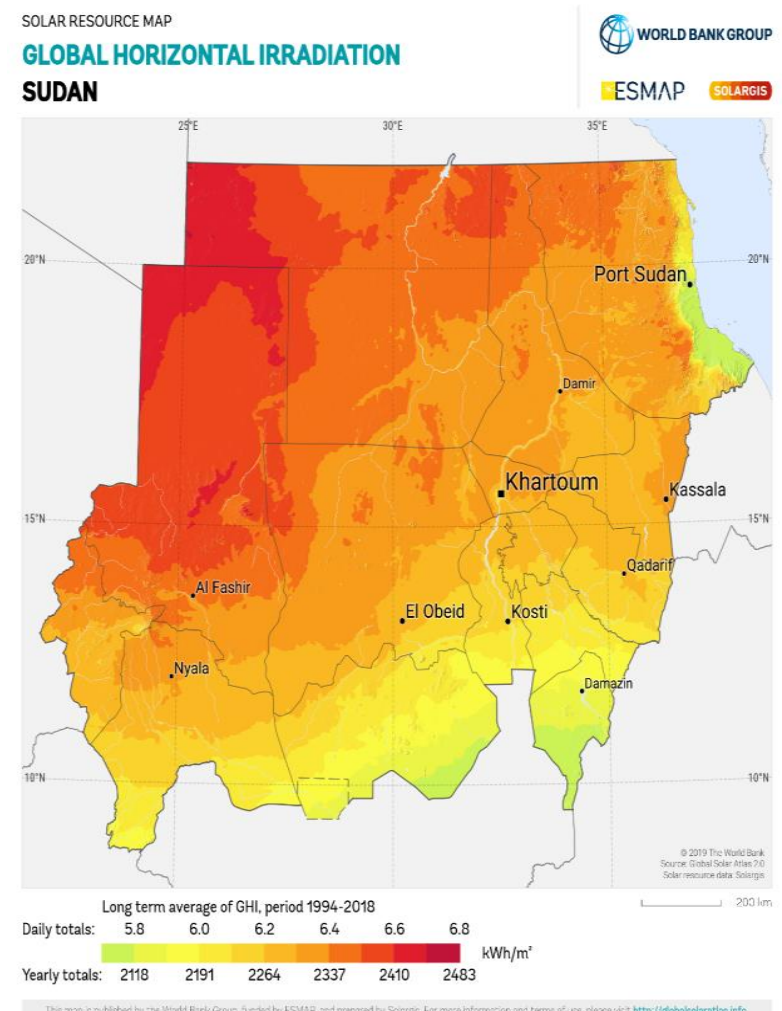

Fig.5. Global Horizontal Radiation Sudan

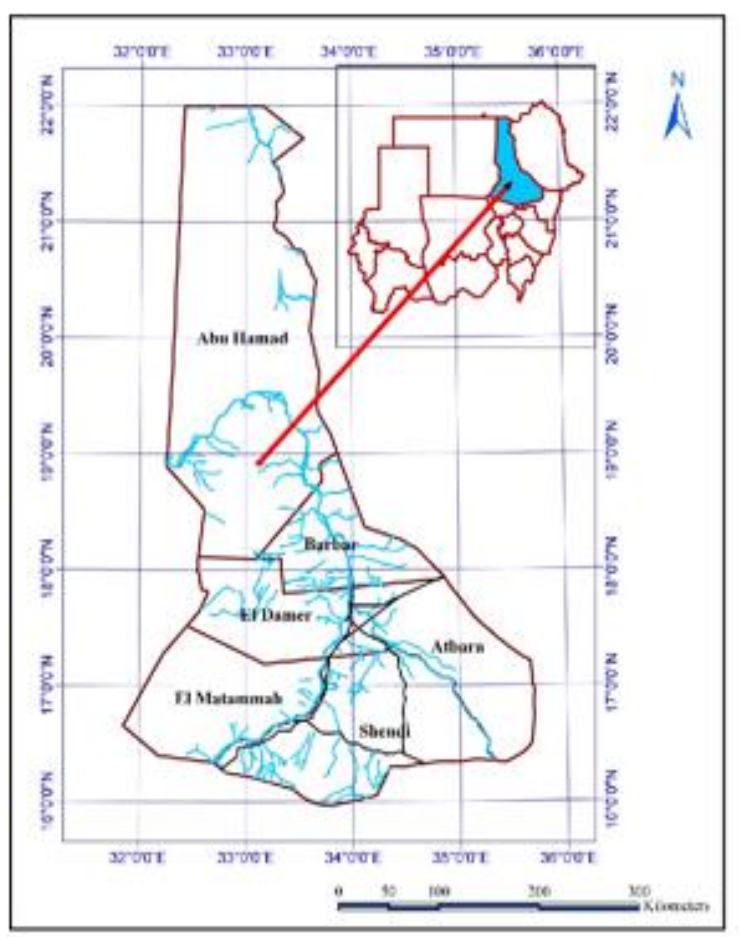

Fig.6. Sudan River Nile State
The River Nile State is famous for its cement industry, which is a flourishing industry in the state, and it has many untapped minerals, such as mica. The state is very rich in this important mineral, and there are also some other minerals, such as gold that the people extract randomly [16]. The River Nile State composed of 6 famous localities Shendi, El Matammah, Atbra, El Damer, Barbar and Abu Hamad. The Solar radiation as illustrated in Figure 5, fall between $6.67 \mathrm{KWh} / \mathrm{m} 2 /$ day and $7.09 \mathrm{KWh} / \mathrm{m} 2 /$ day $),(2,434.55-2,587.8 \mathrm{KWh} / \mathrm{m} 2 /$ year $)$ which is quite sufficient to encourage investment in SPV and CSP. Simulation Study For solar energy potential and CSP assessments all River Nile State Localities will be studied Abu Hamad, Barbar, El Damer, Atbara, Shendi and El Matammah. SAM software is used to simulate the implementation of CSP Parabolic Troughs 100 MWe with Thermal Energy Storage 6 hours of storage at design point without considering the Financial Model in the simulation and Results.

\section{A. Simulation Study}

For solar energy potential and CSP assessments, all River Nile State Localities will be studied Abu Hamad, Barbar, El Damer, Atbara, Shendi and El Matammah. SAM software is used to simulate the implementation of CSP Parabolic Troughs 100 MWe with Thermal Energy Storage 6 hours of storage at design point without considering the Financial Model in the simulation and Results.

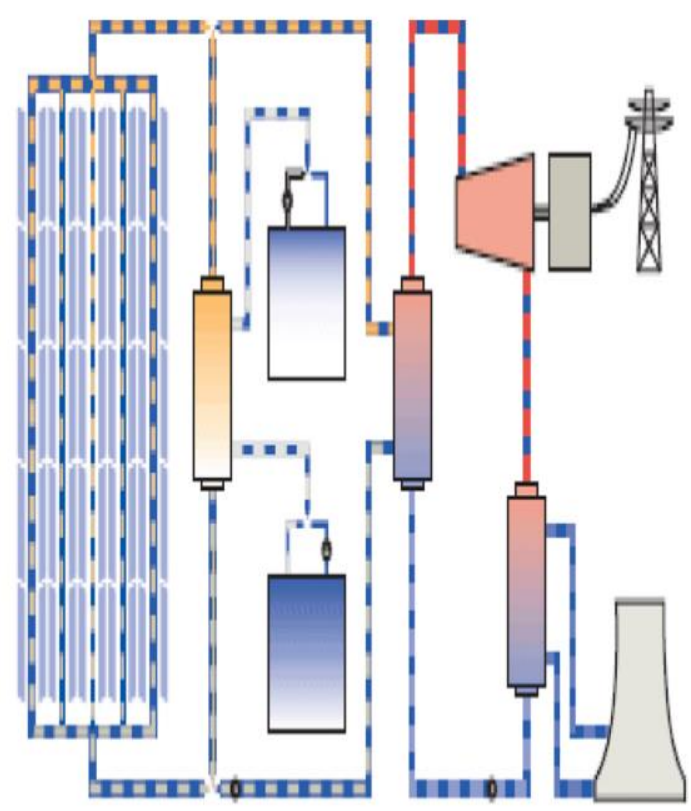

Solar field

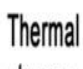

Power block storaece

Fig. 7. Schematic view of parabolic trough power plant [3] 


\section{International Journal of Engineering Applied Sciences and Technology, 2020 \\ Vol. 5, Issue 7, ISSN No. 2455-2143, Pages 13-19 \\ Published Online November 2020 in IJEAST (http://www.ijeast.com)}

\section{SIMULATION RESULTS}

\section{A. Solar energy potential assessment}

Implementing of a Solar Photovoltaic (SPV) Power Plant or Concentrated Solar Power (CSP) Plant requires a prefeasibility study that includes solar energy resource, cost and water supply analysis. The first step in pre-feasibility of SPV and CSP plants is solar energy potential assessment, Total solar horizontal energy, GHI, consists of two terms; Beam Horizontal Irradiation (BHI) and Diffuse Horizontal Irradiation [2]. It is generally assumed that solar concentrating systems only is considered as economically visible for locations with direct incidence radiation (DNR) above 1800 kWh m-2 year-1 [10].

Table -2 Annual Average Calculated from Weather File (SAM)

\begin{tabular}{|c|c|c|c|c|c|c|}
\hline $\begin{array}{l}\text { Localit } \\
\text { y Name }\end{array}$ & $\begin{array}{l}\text { Lat/ } \\
\text { Long }\end{array}$ & $\begin{array}{c}\text { GH } \\
(\mathbf{K W h} \\
/ \mathbf{m} 2 / \mathbf{d} \\
\text { ay) }\end{array}$ & $\begin{array}{c}\text { DNR } \\
(\mathrm{KWh} \\
/ \mathrm{m} 2 / \mathrm{d} \\
\text { ay) }\end{array}$ & DH & $\begin{array}{c}\text { Avg. } \\
\text { Tempa } \\
\text { ture C }\end{array}$ & $\begin{array}{l}\text { Avg. } \\
\text { Wind } \\
\text { speed }\end{array}$ \\
\hline Shendi & $\begin{array}{c}1_{16.6743}^{\circ} \\
\mathrm{N}, \\
33.4496^{\circ} \\
\mathrm{E}\end{array}$ & 6.78 & 6.87 & 2.01 & 29.6 & 4.7 \\
\hline $\begin{array}{c}\text { El } \\
\text { Matam } \\
\text { mah }\end{array}$ & $\begin{array}{c}1_{16.7132^{\circ}} \\
\mathbf{N}, \\
33.3626^{\circ} \\
\mathbf{E}\end{array}$ & 6.67 & 6.66 & 2.06 & 29.7 & 4.7 \\
\hline Atbra & $\begin{array}{c}\mathbf{1 7 . 7 0 1 5}^{\circ} \\
\mathbf{N} \\
\text { 34.0084 }^{\circ} \\
\mathbf{E}\end{array}$ & 6.75 & 6.87 & 2.03 & 29.8 & 4.7 \\
\hline $\begin{array}{c}\text { El } \\
\text { Damer }\end{array}$ & $\begin{array}{c}17.59898 \\
\text { 33.97205 }\end{array}$ & 6.78 & 6.9 & 2.02 & 30.2 & 4.7 \\
\hline Barbar & $\begin{array}{c}18.0295^{\circ} \\
\mathrm{N}, \\
33.9917^{\circ} \\
\mathrm{E}\end{array}$ & 6.76 & 6.95 & 1.99 & 29.9 & 4.7 \\
\hline $\begin{array}{c}\text { Abu } \\
\text { Hamad }\end{array}$ & $\begin{array}{c}19.5356^{\circ} \\
\mathrm{N}, \\
33.3206^{\circ} \\
\mathrm{E}\end{array}$ & 6.79 & 7.09 & 1.96 & 29.4 & 4.8 \\
\hline
\end{tabular}

The above table shows that all localities the mean Global Horizontal Irradiation (GHI) is more than $1800 \mathrm{kWh} / \mathrm{m} 2$ and are suitable for both Solar Photovoltaic Power Plants and Concentrated Solar Power Plants (CSP). the yearly DNR (KWh/m2/year) obtained gives the priority of selection by ranking to the Localities as follows: Abu Hamad (1), Barbar (2), El Damer (3) Atbara and Shendi (4) and the last is El Matammah (5). Figure 7 and Figure 8 represented the daily average Global and Direct Normal Radiation over the River Nile State.
Global Horizontal Radiation (KWh/m2/day)

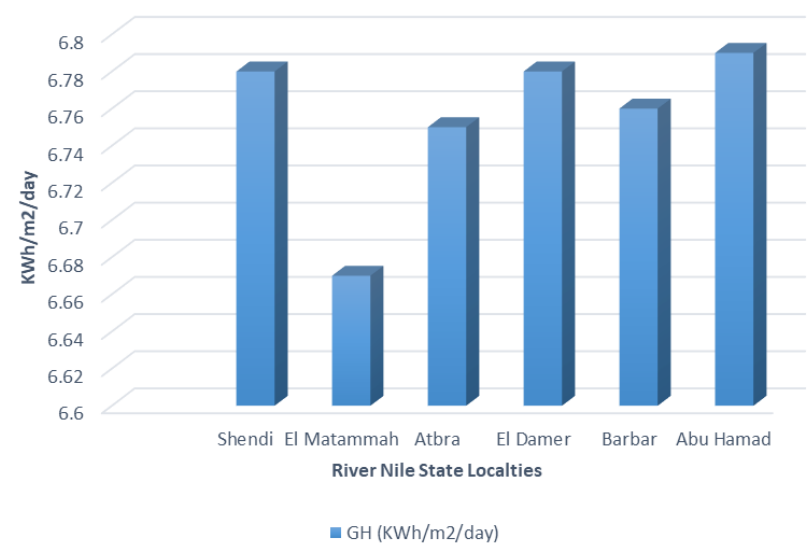

Fig.7. Global Horizontal Radiation River Nile State

\section{$B$. CSP plant performance assessment}

The analysis of the parabolic trough Concentrated Solar Power Plant performance is applied by using National Renewable Energy Laboratory's (NREL) SAM software. SAM provides the modelling capability for several technologies including the parabolic trough technologies [17]. SAM combines an hourly simulation model with performance, cost and finance models to calculate energy output, energy costs and cash flows. The chosen parabolic trough Concentrated power station system features a capacity of 100 MW nameplate capacity and 6 hours thermal Energy storage (TES).

The annual electricity generated by the parabolic trough plant in River Nile localities is illustrated in table 3 below.

Table -3 Annual performance parameters

\begin{tabular}{|c|c|c|}
\hline Selected Localities & $\begin{array}{c}\text { Annual Energy } \\
\text { Output (GWh) }\end{array}$ & Capacity Factor \\
\hline Abu- Hamad & $\mathbf{3 8 9 . 4 5}$ & $\mathbf{0 . 4 5}$ \\
\hline Atbra & $\mathbf{3 8 1 . 7 6}$ & $\mathbf{0 . 4 4}$ \\
\hline Barbar & $\mathbf{3 8 5 . 0 2}$ & $\mathbf{0 . 4 4}$ \\
\hline EI Damer & $\mathbf{3 8 3 . 5 8}$ & $\mathbf{0 . 4 4}$ \\
\hline El Matammah & $\mathbf{3 6 3 . 1 4}$ & $\mathbf{0 . 4 1}$ \\
\hline Shendi & $\mathbf{3 8 3 . 2 5}$ & $\mathbf{0 . 4 4}$ \\
\hline
\end{tabular}

The annual electricity generated by the CSP plant is $389 \mathrm{GWh}$ Abu Hamad, 381 GWh Atbra, 385 GWh Barbar, 383 GWh El Damer, El Matammah $364 \mathrm{GWh}$ and $382 \mathrm{GWh}$ Shendi as shown in table 3 above.

\section{Comparison of Results}

An assessment of the electricity generated by CSP solar parabolic trough power plant in the 6 localities of River Nile State in Sudan is done. A comparison of DNI and electricity generation of CSP plant in the 6 selected localities of River Nile State in Sudan is shown in Figure 8 and Figure 9. These 


\section{International Journal of Engineering Applied Sciences and Technology, 2020 \\ Vol. 5, Issue 7, ISSN No. 2455-2143, Pages 13-19 \\ Published Online November 2020 in IJEAST (http://www.ijeast.com)}

figures shows that Abu Hamad and Barber have the highest solar potential due to their higher received solar radiation and better weather conditions with comparison to El Matammah locality, the lowest solar potential among the selected localities.

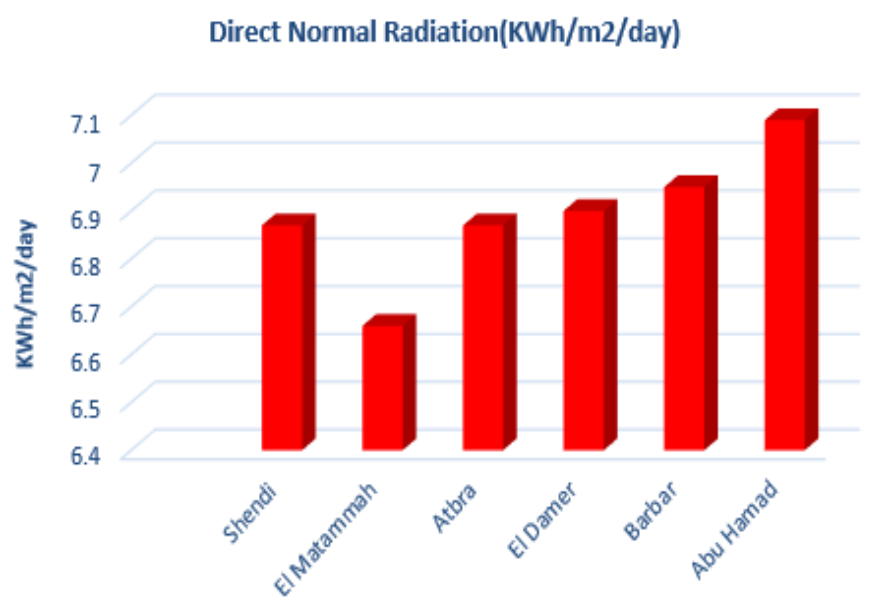

Fig.8. Direct Normal Incident Radiation River Nile State

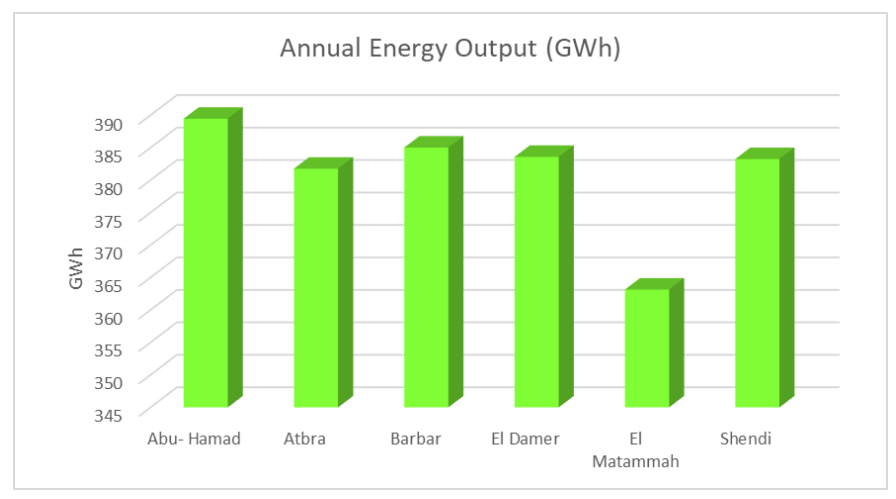

Fig.9. Annual Energy Output River Nile State

\section{Mitigation of Carbon Emissions and Fuel Preservation}

Coal and petroleum are also called fossil fuels or nonrenewable energy resources. One way of fuel conservation is to avoid their wastage by switching to alternative sources such as solar energy. Concentrated Solar Power plants (CSP) help to preserve fossil fuels and result in $\mathrm{CO} 2$ reduction. An amount of $0.285 \mathrm{~m} 3$ natural gas is needed to generate $1 \mathrm{kWh}$ electricity accounted for $34 \%$ efficiency [18] and $1 \mathrm{kWh}$ electricity generation for Sudan is equivalent to $0.615 \mathrm{~kg} \mathrm{CO} 2$ ( $1 \mathrm{~m} 3$ natural gas $=1,9 \mathrm{~kg} \mathrm{CO} 2$ ) [19][20]. Table 4 shows the amount of reducing $\mathrm{CO} 2$ emission and natural gas preservation for the considered plant in the selected cities.
Table -4 the amount of yearly fuel preservation and $\mathrm{CO} 2$ mitigation results from using CSP in the selected Localities

\begin{tabular}{|c|c|c|c|c|c|c|}
\hline & 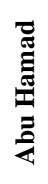 & 苞 & 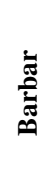 & 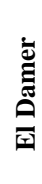 & 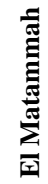 & जँ \\
\hline ชి & 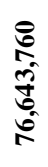 & 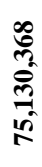 & हू & 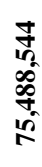 & 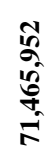 & 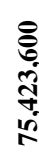 \\
\hline 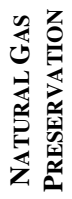 & है & 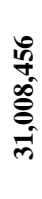 & กี & 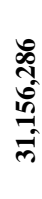 & 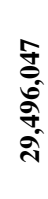 & $\begin{array}{l}\bar{\infty} \\
\stackrel{+}{0} \\
\stackrel{-}{-}\end{array}$ \\
\hline
\end{tabular}

V. CONCLUSION

The National resources available in River Nile State is quite sufficient to support nexus between energy, food, water and land use to offers an approach for multi-scale, integrated assessment of this nexus. The assessment of the solar energy potential contribution (quantity) and convenience (quality) of concentrated solar power (CSP) as alternative sources for the production of electricity in River Nile State concluded that:

1. The site of Abu Hamad locality has the highest solar potential to generate electricity followed by Barbar, El Damer, Atbara, and Shendi and finally El Matammah has the lowest potential among them.

2. From the sites analysed all state localities have areas with plenty of water and therefore no restrictions on using parabolic trough technique.

3. Fossil fuel can be preserved considerably in these areas and can obtain about 76 Million Cubic Meters of $\mathrm{CO} 2$ emission-reducing and about 31 Million Cubic Meters Natural gas-saving with the line of the sustainable development program.

I. For Abu Hamad locality, CSP the size assumption for power plant of 100MW yield a result of Energy, Land and Water nexus as flows: The solar field area is 587 acres with non-solar field land area multiplier 1.4 which gives a total plant area of 822 acres (8.22 acres per MW of power capacity). 


\section{International Journal of Engineering Applied Sciences and Technology, 2020 \\ Vol. 5, Issue 7, ISSN No. 2455-2143, Pages 13-19 \\ Published Online November 2020 in IJEAST (http://www.ijeast.com)}

II. Average solar radiation $2,587 \mathrm{Wh} / \mathrm{m} 2 /$ year. The outputs are $562 \mathrm{GWh}$ thermal annually (provided by solar radiation); and 389 electricity annually (produced by the plant).

III. Total Annual Water usage is $84,238 \mathrm{~m} 3$

\section{REFERENCE}

[1] Mario G, Richard J. Aspinall, Jesus Ramos, and Sandra G.F.(2015), Resource Accounting for Sustainability Assessment The nexus between energy, food, water and land use.

[2] M. Enjavi-Arsanjani, Solar energy potential and performance assessment of CSP plants in different areas of Iran, Energy Procedia , ( 2015 ) 69, (pp.2039-2048).

[3] T.M. Pavlovi'c, (2012). A review of concentrating solar power plants in the world and their potential use in Serbia, Renewable and Sustainable Energy Reviews, , 16, (pp.3891-3902).

[4] Markovic' D, Ceperkovic' B, Vlajcic' A, Ressl S. (2011). The white book of the electric power industry of Serbia. Belgrade: PE Electric Power Industry of Serbia;.

[5] Ummadisingu A, Soni MS., (2011). Concentrating solar power - technology, potential and policy in India. Renewable and Sustainable Energy Reviews; 15(9), (pp.5169-75).

[6] B. Belgasim, (2018). The potential of concentrating solar power (CSP) for electricity generation in Libya, Renewable and Sustainable Energy Reviews 90 (pp. 115)

[7] Africa Energy Outlook (2019). INTERNATIONAL ENERGY AGENCY, www.iea.org/africa2019

[8] The National Renewable Energy Laboratory is a national laboratory of the U.S. Department of Energy, https://www.nrel.gov/about/mission-programs.html

[9] Annual report (2019). Load Dispatch Center-Ministry of Energy and Mining, Sudan

[10] Müller-Steinhagen H, Trieb F., (2004). Concentrating solar power. A review of the technology Ingenia Inform QR Acad Eng 2004; 18, (pp.43-50).

[11] Abbas M, Belgroun Z, Aburidah H, Merzouk N K. (2013). Assessment of a solar parabolic trough power plant for electricity generation under Mediterranean and arid climate conditions in Algeria. Energy Procedia 2013; 4, (pp:93-102).

[12] Donaji M A, Lourdes G M. (2015). Comparative study of concentrated solar power plants with Solar Advisor Model. SolarPACES 2010; Perpignan, France2010.
[13] Malagueta D, Szklo A, Soria R, Dutra R, Schaeffer R, Moreira Cesar Borba B S. (2014) Potential and impacts of concentrated solar power (CSP) integration in the Brazilian electric power system. Renewable Energy; 68, (pp.223-35).

[14] Purohit I. Techno-economic aspects of concentrating solar power (CSP) in India

[15] http://clickgrafix.co/council/index.php/ar/pages/details/9/ 2

[16] http://nilegate.gov.sd/

[17] I. Llorente Garcia, (2011). Performance model for parabolic trough solar thermal powerplants with thermal storage: Comparison to operating plant data, Solar Energy 85 (2011), (pp. 2443-2460).

[18] Sudanese Thermal Generating Company

[19] Brander M, Sood A, Wylie C, Haughton A, Lovell J. (2011) Electricity-specific emission factors for grid electricity, emissionfactor.com

[20] Conversion Guidelines - Greenhouse gas emissions https://www.innovasjonnorge.no/globalassets/eeagrants/joint-application-documents/er_6-conversionguidelines-ghg.pdf 